\title{
Introduktion
}

\section{Kalaallit pilluaritsi: Perspektiver på 10 års Selv- styre, 40-året for Hjemmestyrets indførelse og vejen til selvstændighed}

\author{
Marc Jacobsen, ph.d-stipendiat, Institut for Statskundskab, Københavns Universitet
}

Rebekka J. Knudsen, projektleder for Greenland Perspective, Københavns Universitet \& Ilisimatusarfik

\section{Minik T. Rosing, professor, Statens Naturhistorisk Museum, Københavns Universitet}

Når det grønlandske flag, Erfalasorput, den 21. juni 2019 igen går til tops på officielle bygninger i Danmark, er der ikke blot tale om en festlig markering af Grønlands nationaldag. Flaghejsningen symboliserer samtidig det danske ønske om at bibeholde Grønland som en del af Rigsfællesskabet ${ }^{\mathrm{ii}}$. Det er også en anerkendelse af, at grønlænderne er et folk med ret til selvbestemmelse - som Danmark anerkendte det med formuleringerne i Selvstyreloven, der trådte i kraft for præcis 10 år siden. Markante grønlandske politikere har siden da funderet over og debatteret, hvad næste trin på selvstændighedsstigen skal byde på, og hvornår det skal tages. Meningerne er mange, men de fleste er enige om, at øget grønlandsk selvbestemmelse er værd at stræbe efter. Hvad der imidlertid ofte drukner, når debatterne bliver ophidsede, er de mange facetter af selvstændighedsspørgsmålet, som også bør være en del af debatten, så det ikke kun handler om ideologi og økonomi.

Ønsket med dette temanummer er at bidrage til en mere nuanceret debat og give et flersidigt billede af, hvilke muligheder, udfordringer og dilemmaer, Grønland vil stå overfor, hvis selvstyre afløses af fuld grønlandsk autonomi. Temanummeret har derfor ikke til hensigt at give en vurdering af, hvorvidt selvstændighed er muligt at realisere. I stedet er ambitionen at bidrage til en mere kvalificeret debat om, hvordan selvstændighed vil påvirke samfundet på mange forskellige områder. Bidragene dækker tilsammen jura og offentlig administration; økonomi og erhverv; kultur og identitet; medier og journalistik samt udenrigspolitik og internationale relationer.

Roden til selvstændighedsdebatten

Med en vis ret kan man hævde, at tanken om grønlandsk løsrivelse fra Danmark med skiftende intensitet har floreret siden kolonitiden formelt set blev afsluttet, og Grønland i 
1953 fik status af dansk amt. I 1970'erne fik grønlandsk nationalisme for alvor vind i sejlene, hvilket blandt andet manifisterede sig i kunst og kultur. Det populære, Doorsinspirerede rockband Sumé pirkede til selvstændighedstankerne med deres sange om grønlandsk stolthed og dansk undertrykkelse ${ }^{\mathrm{iii}}$. Samtidig voksede en ny generation af selvbevidste grønlandske politikere frem, og i 1979 blev Hjemmestyret indført. Under ledelse af Siumuts harmonikaspillende landsstyreformænd Jonathan Motzfeldt og Lars Emil Johansen - og med betydelig indflydelse fra Moses Olsen ${ }^{\text {iv }}$ - blev et nyt politisk system realiseret på kort tid i løbet af 1980'erne ${ }^{\mathrm{v}}$. Bloktilskuddet på 3,6 milliarder kroner blev indført, og Grønland overtog dermed ansvaret for skole, kultur, skat, sociale forhold samt den såkaldte landsplanlægning. Landet fik sit eget universitet og dermed var et vigtigt frø på vejen mod større uafhængighed sået. Med "den grønlandske Leonard Cohen", IA-politikeren Kuupik Kleist - som var kendt for sin mørke sangstemme - i spidsen markerede Grønland i 2009 et nyt og afgørende skridt på vejen mod selvbestemmelse: Efter års dansk-grønlandske forhandlinger stemte tre fjerdedele af de grønlandske vælgere ved en folkeafstemning i 2008 for Selvstyre. Med aftalen fulgte en liste på 32 sagsområder, som Grønland fik mulighed for at hjemtage. Den er der så småt blevet taget hul på: råstoffer, de gymnasiale uddannelser og arbejdsmiljø. Der er stadig 29 områder tilbage, før dén del af Selvstyrelovens muligheder er udtømt.

For både almindelige borgere og langt de fleste politikere i Grønland, er en større grad af selvbestemmelse og måske endda fuld løsrivelse fra Rigsfællesskabet et stort ønske. I en meningsmåling fra udgangen af 2016 svarede 64 procent af de adspurgte, at de mente, at selvstændighed for Grønland enten var meget eller noget vigtigt (Skydsbjerg \& Turnowski 2016). De unge var mindre optagede af selvstændighedsspørgsmålet end de ældre, men på tværs af generationerne var der et klart flertal, der ønskede, at Grønland skal være et selvstændigt land. Målingen blev dog efterfølgende kritiseret for ikke at indeholde spørgsmål om, hvorvidt man også ønskede selvstændighed, ifald konsekvensen blev et væsentligt fald i levestandard. Det blev der rådet bod på i 2017, da en ny måling kunne fortælle, at 44 procent går ind for selvstændighed, hvis det ikke forringer de nuværende vilkår, mens 11 procent ønsker ubetinget selvstændighed og 12 procent kun ville kunne acceptere en lille forringelse (Turnowski 2017). I 2018 gennemførte et forskerhold, på tværs af 13 grønlandske byer og bygder, en kortlægning af overbevisninger, holdninger og handlinger i forbindelse med de klimatiske, politiske og bymæssige forandringer, som finder sted i disse år. Foreløbige resultater fra undersøgelsen, som går under navnet Greenlandic Perspectives, har blandt andet vist, at befolkningen er delt i tre næsten lige store dele, når det gælder spørgsmålet om, hvorvidt Grønland bør blive helt uafhængigt af Danmark indenfor de næste ti år. Knap 36 procent erklærer sig positive overfor tanken om et selvstændigt Grønland. Økonomiske overvejelser er i høj grad med til at forme holdningen, og undersøgelsen viste, at hovedparten af de, som ønsker selvstændighed, også tror på, at det vil gavne den grønlandske økonomi (Agneman \& Minor 2018).

Ønsket om at blive et selvstændigt land manifesterede sig også i valgkampen i foråret 2018. Her stod Kim Kielsen tilbage som sejrherre og kunne igen danne koalition 
med Siumut for bordenden. Selvom spørgsmålet om selvstændighed langt fra var det tema, der fyldte mest i den grønlandske valgkamp, var det dog - måske særligt internt i partierne - et spørgsmål, der blev en vigtig fløjmarkør, og førte til dannelsen af flere nye partier. Én skillelinje gik groft sagt mellem dem der, som Kielsen, mener, at forberedelserne til en eventuel løsrivelse vil være årtier, hvis man skal undgå tunge konsekvenser for den almene befolkning - og så de mere radikale, der giver udtryk for, at Danmark står så meget i vejen for Grønlands udvikling, at løsrivelse må komme først, hvis man nogensinde skal blive selvstændig. I den anden ende af det politiske spektrum, er der nu - igen - blevet plads til et parti, der holder så meget af Rigsfællesskabet, at man eksplicit erklærer sig imod løsrivelse.

I både Danmark og Grønland tager debatten om selvstændighed ofte en form, der til forveksling kan ligne debatter om EU. Det bliver hurtigt et spørgsmål om 'ja' eller 'nej' til selve ideen. Og om økonomi, krydret med et pift af sikkerhedspolitik ${ }^{\mathrm{vi}}$. For kan det overhovedet lade sig gøre for Grønland at blive et selvstændigt land, når man har en befolkning på størrelse med Horsens, spredt ud over et område på størrelse med Vesteuropa? Kan et land med drømme om store internationale lufthavne og minedrift - men som ikke kan finansiere dem uden investeringer udefra - undgå at ende i lommen på amerikanerne eller kineserne? I 2011 påbegyndte Naalakkersuisut forarbejdet til en kommende grønlandsk grundlov. Den daværende Naalakkersuisoq for selvstændighed tog på turné i hele landet for at informere om arbejdet. Møderne blev fra flere sider kritiseret for udelukkende at fokusere på arbejdet med en forfatning uden mere detaljeret at adressere, hvordan grønlænderne kunne tænkes at blive berørt af en kommende selvstændighed. Det store spørgsmål om 'ja' eller 'nej' kom dermed til at skygge for de mere nuancerede spørgsmål om - og dermed en mere oplyst diskussion af - hvad selvstændighed egentlig er, og hvad den vil komme til at betyde for de enkelte samfundsområder og for Grønland som helhed. I skrivende stund gøres endnu et forsøg på at genstarte processen i en ny udgave af Forfatningskommissionen, hvis kommissorium blev ændret i slutningen af marts 2019, så det nu alene skal udarbejde et udkast til en forfatning for et selvstændigt Grønland (Naalakkersuisut 2019).

Kalaallit pilluaritsi

Jubilæumsdagen 21. juni 2019 - 10 år for Grønlands Selvstyre og 40 år for Hjemmestyret - er en oplagt anledning til at forsøge at grave et spadestik dybere. Hvordan kan fremtidens Grønland komme til at forme sig, hvis ønsket om løsrivelse bliver til virkelighed? Selvstændighedsspørgsmålet bliver ofte diskuteret i en dansk kontekst, hvor danske meningsdannere, forskere, og politikere dominerer, mens grønlandske stemmer uden for de politiske kredse sjældent kommer til orde. Ambitionen med dette temanummer er at give et talerør til nogle af de grønlandske stemmer, som har særligt indgående kendskab til nogle af de mest centrale sektorer, der vil blive berørt af en løsrivelse fra Rigsfællesskabet. Med udgangspunkt i deres egne erfaringer og indsigt reflekterer de over status på 
netop deres område: Hvad er den historiske udvikling? Hvor er udviklingen på vej hen? Med hvilke mulige konsekvenser? Hvad skal der til for at tage næste skridt på selvstændighedsstigen? Temanummeret er ikke et forsøg på at fælde dom over, hvorvidt selvstændighed for Grønland er ønskværdig eller mulig, men at bidrage til en mere kvalificeret og nuanceret debat ved at belyse nogle potentielle konsekvenser og centrale spørgsmål inden for de enkelte samfundsområder.

Den grønlandske samfundsmodel ligner på en lang række områder den danske. Kritikere mener, at Grønland dermed har spildt noget af det potentiale, som Hjemmestyre og Selvstyre egentlig ville kunne have forløst. Samfundsmodellen er imidlertid ikke tilpasset til arktiske forhold og det har skabt et samfund, der er dyrt i drift set i forhold til landets størrelse og befolkning. Spørgsmålet er om og hvordan en løsrivelse fra Danmark vil ændre på dette i dag, hvor Grønland selv er blevet en aktør på den globale scene. Hvordan vil Grønland for eksempel stille sig på udenrigsområdet ${ }^{\text {vii }}$, og hvilke internationale samarbejdspartnere vil man vælge? Allerede i dag går bølgerne højt, når mulige partnerskaber med blandt andet Kina og USA diskuteres. I efteråret 2018 fik et tilbud fra den danske statsminister om et substantielt bidrag til finansiering af flere internationale lufthavne i Grønland dele af den grønlandske befolkning til at rynke på næsen og politikere til at smække med døren. Tilbuddet ramte lige ned i diskussionen om, hvor stor indflydelse Danmark skal have i Grønland, og man var bange for at blive underlagt krav om dansk indflydelse. Resultatet var, at regeringskoalitionen gik i opløsning.

Også på de områder, der er tæt på borgernes hverdag, står de interessante dilemmaer i kø: Hvordan vil man sikre tilstrækkelig kapacitet i og bemanding af den offentlige service? Kan de grønlandske medier kompensere for, at danske journalister i endnu mindre grad end i dag vil interessere sig for grønlandske forhold, hvis Grønland træder ud af Rigsfællesskabet? Hvordan sikrer man, at alle har adgang til et varieret medieudbud, der understøtter udviklingen af en nation? Og kan man overhovedet sikre armslængde og uafhængighed til kritisk journalistik i et samfund med kun 57.000 borgere? Selvstændighed er meget mere end praktikaliteter. Det er i meget høj grad et spørgsmål om følelser. Kultur og identitet ${ }^{\text {viii }}$ ikke mindst. Hvordan vil det påvirke den grønlandske kultur, hvis løsrivelse bliver til virkelighed og Grønland skal finde nye tætte internationale allierede i stedet for Danmark? Der findes formentlig ikke mange eksempler på grønlændere, der ikke er familiemæssigt knyttet til Danmark. Hvad vil en løsrivelse betyde for deres identitet? Og hvordan udvikles samfundet $\mathrm{i}$ retning af selvstændighed, når det eksempelvis samtidig er et ønske om at bevare fangsttraditioner og overlevering af disse, i en tid hvor prisvenlige forarbejdede fødevarer er let tilgængelige på hylderne og hvor klimaforandringer ${ }^{\text {ix }}$ grundlæggende ændrer de "traditionelle" grønlandske levevilkår? Disse spørgsmål - og mange flere - ligger til grund for arbejdet med dette temanummer, som vi håber, vil bidrage til en mere oplyst og nuanceret diskussion af, hvilke muligheder, udfordringer og dilemmaer Grønland kan tænkes at stå overfor, hvis selvstyre afløses af selvstændighed. 


\title{
Resuméer af temanummerets artikler
}

\author{
Jakob Janussen | Grønlands vej til større selvbestemmelsesret: Muligheder og \\ begrænsninger $\mathrm{i}$ juridiske, administrative og andre perspektiver
}

Det grønlandske folks inddragelse i landets styring siden 1860 var i begyndelsen stærkt begrænset. Først ved hjemmestyrets indførelse i 1979 fik det lokale parlament i Grønland egentlig lovgivningskompetence på visse områder. Alle større sagområder overtaget fra den danske stat blev ledsaget af et bloktilskud. Hjemmestyreloven blev afløst af en selvstyrelov i 2009. Listen over de sagsområder, som kunne overtages fra staten, blev udvidet betragteligt. Udgifter vedrørende sagsområder, som selvstyret kan overtage, skal afholdes af selvstyret selv. De formelle begrænsninger for det grønlandske folks ret til større selvbestemmelse er formindsket betydeligt, specielt i den allerseneste tid. Mulighed for selvbestemmelse begrænses dog også af bl.a. geografiske, befolkningsmæssige og erhvervsmæssige forhold. Det grønlandske samfund er endvidere karakteriseret ved den offentlige sektors dominans. Dette er en væsentlig forhindring for at Grønlands økonomi kan blive mere selvbærende. Selvom de formelle begrænsninger i grønlandsk ret til selvbestemmelse er blevet reduceret, sætter andre forhold en grænse for en realisering af denne ret.

\section{Nauja Bianco | Ender Grønlands økonomi og erhvervsudvikling i fisk?}

Hvilke dilemmaer og udfordringer står Grønland overfor i lyset af ønsket om fremtidig selvstændighed? Artiklen dykker ned i de centrale spørgsmål, der knytter sig til økonomien og erhvervsstrukturen i Grønland og reflekterer over, hvad udviklingen på disse områder fortæller os om det grønlandske samfund i dag og dets muligheder i en fremtid, der kan byde på løsrivelse fra Rigsfællesskabet. Artiklen viser, at - udover bloktilskuddet fra Danmark og aftalte indtægter fra EU, som udgør ca. 60 procent af Selvstyrets indtægter - grundlaget for Grønlands økonomi og erhvervsstruktur siden 1950'erne og 60'erne har været fiskeriet, der stadig blomstrer. Artiklen viser dog også, at Grønlands økonomi er enkeltstrenget og dermed følsom overfor udsving og ikke alene kan dække indkomstbehovet for et selvstændigt Grønland. Artiklen påpeger, at selvstændighed vil kræve, at den grønlandske økonomi diversificeres og at erhvervsstrukturen udvikles. Særligt kunne den marine industri indenfor bioøkonomi udgøre et potentiale for innovation og produktudvikling. Der er også plads til iværksætteri inden for den kulturelle og kreative industri. Turismeindustrien skal fortsat udvikles, og en omfattende strategi for at tiltrække udenlandske og direkte investeringer til Grønland bør udvikles. 
Naja Carina Steenholdt | Livsformer \& livskvalitet i Grønland: Et indblik i sammenhængen og den potentielle udvikling

I denne artikel undersøges det nærmere, hvordan livsformer og livskvalitet hænger sammen i Grønland set $i$ et samfundsvidenskabeligt perspektiv. Artiklen forholder sig endvidere til, hvordan dette hænger sammen med landets udvikling mod selvstændighed. Livskvalitet og forestillingen om det gode liv hører til det kulturelle og værdiladede i en livsform. Det er med andre ord en forestilling om, hvordan tingene bør, skal, eller kan være, for at vi kan føle, at livet er godt. Men det betyder også noget, hvor man bor. Det er en klassisk opfattelse, at man har en væsentligt anderledes livsform i en by kontra en bygd, og har forskellige værdier og holdninger til, hvad livskvalitet kan være. Artiklen, som er et indledende studie på området, vil på baggrund af resultater fra et sociologisk feltarbejde i Sydgrønland i 2018, samt gennem en analyse og diskussion af livskvalitet og etnologen Thomas Højrups livsformsanalyse, stille spørgsmålene: Hvordan hænger livsformer og livskvalitet sammen i Grønland? Og er der en sammenhæng med den nuværende udvikling mod selvstændighed? Artiklen fremfører, at livsformer og livskvalitet i høj grad er forbundet med relationer til familie, natur og arbejde, men at det grønlandske folks evne til at tilpasse sig også spiller en rolle i forholdet mellem livsformer og livskvalitet.

\section{Signe Ravn-Højgaard | Medier og selvstændighed i Grønland}

Denne artikel diskuterer, hvad grønlandsk selvstændighed vil kunne tænkes at betyde for mediesystemet i Grønland, samt hvilke tiltag, der kan være nødvendige for at bevare stærke grønlandske medier i fremtiden. Først beskrives mediesystemet i Grønland ved hjælp af Manuel Puppis' (2009) teori om særtræk ved mediesystemer i små stater. Det ses, at det grønlandske mediesystem er opbygget ud fra en målsætning, hvor medierne skal understøtte det grønlandske samfund ved at være uafhængige og mangfoldige, styrke det grønlandske sprog og levere kvalitetsjournalistik, der kan løfte samfundsdebatten. Det grønlandske mediesystem er småt og sårbart over for bl.a. globale tendenser, der medfører, at traditionelle medier mister brugere og annonceindtjening til digitale platforme som Facebook og streaming-tjenester. Artiklen argumenterer for, at mediernes sårbarhed bliver større, hvis Grønlands selvstændighed medfører strammere offentlig økonomi, hvilket kan gøre det sværere for dem at udfylde deres funktion i samfundet. En interventionistisk medieregulering kan derfor være en forudsætning for stærke grønlandske medier, der kan udgøre en samlende og nationsopbyggende institution. 
Mininnguaq Kleist | Gronlands udenrigspolitik og internationale relationer: Nuværende rammer og mulig udvikling i et selvstændighedsperspektiv

Indledningsvist introducerer artiklen de juridiske og politiske rammer for Grønlands internationale og udenrigspolitiske ageren under nugældende selvstyrelov og den danske grundlov. Selvom Danmark i henhold til grundloven besidder kompetencerne i kongeriget for udenrigspolitikken, gøres det også klart, at virkeligheden er en smule mere kompliceret, og at Grønland ikke er uden sine kompetencer, rettigheder og demokratisk ansvar for det grønlandske folk indenfor udenrigspolitikken. Med udgangspunkt i Grønlands tidligere koloni-status under FN og folkeretten for kolonier, samt førnævnte lovgivning, behandles Grønlands udenrigspolitiske udviklingsmuligheder i et selvstændighedsperspektiv. Mulighederne under en mulig forbundsstats-model eller et Free Association-forhold med Danmark berøres, hvoraf sidstnævnte fremhæves som værd at stræbe efter. Artiklen går ikke i dybden med enkeltsager, men fokuserer på rammer og relevante emner, såsom sikkerhedspolitik, medlemskaber af mellemfolkelige organisationer og praktiske aspekter som kapacitetsovervejelser. 
Litteraturliste

Ackrén, M. (2014). Greenlandic Paradiplomatic Relations. I: Heininen, L. (ed.) Security and Sovereignty in the North Atlantic. London: Palgrave Macmillan, s. 42-61. DOI: https://doi.org/10.1057/9781137470720_4

Agneman, G \& Minor, K (2018). Greenlandic Perspectives Survey. Tilgængelig på: https://samf.ku.dk/nyheder/i-groenland-maerker-de-klimaforandringerne-paa-egen-krop/ [Tilgået d. 4. maj 2019].

Bjørst, L. (2012). Politiske positioner og skift i den grønlandske klimadebat fra 2001 til 2011. Grønland, årg. 60(1), s. 2-19.

Bjørst, L. (2018). The right to 'sustainable development' and Greenland's lack of a climate policy. I: Gad, U. \& Strandsbjerg, J. (red.), The Politics of Sustainability in the Arctic. New York: Routledge, s. 121-135.

Breum, M. (2014). Balladen om Grønland - trangen til løsrivelse, råstofferne og Danmarks dilemma. København: Gyldendal.

Gad, U.P. (2005). Dansksprogede grønlænderes plads i et Grønland under grønlandisering og modernisering. En diskursanalyse af den grønlandske sprogdebat - læst som identitetspolitisk forhandling, København: Afdeling for Eskimologi og arktiske studier (Eskimologis Skrifter no. 19)

Gad, U.P. (2016). National identity politics and postcolonial sovereignty games. Greenland, Denmark and the European Union. Meddelelser om Grønland 353, Man \& Society 43. København: Museum Tusculanum Publishers.

Gad, U.P. (2017). What kind of nation state will Greenland be? Securitization theory as a strategy for analyzing identity politics. Politik, årg. 20(3), s.104-120. https://doi.org/10.7146/politik.v20i3.97156

Hjemmestyreloven (1979). Lov nr. 577 af 29. november 1978 om Grønlands Hjemmestyre, Inatsisartut. Tilgængelig på: https://ina.gl/media/2529984/hjemmestyreloven-dkpluskal.pdf [Tilgået d. 22. november 2018].

Høiris, O. \& Marquadt, O. (2011). Fra vild til verdensborger. Århus: Aarhus Universitetsforlag.

Jacobsen, M. (2015). The power of collective identity narration: Greenland's way to a more autonomous foreign policy. Arctic Yearbook 2015. Akureyri: Northern Research Forum, s. 102-118.

Jacobsen, M. (2019a forthcoming). Greenland's Arctic Advantage: articulations, acts and appearances of sovereignty games. Cooperation \& Conflict.

Jacobsen, M. (2019b forthcoming). Arktis: Grønlands strategiske arena for større udenrigspolitisk suverænitet. Politica.

Jacobsen, M. \& Gad, U.P. (2018). Setting the scene in Nuuk: Introducing the cast of characters in Greenlandic foreign policy narratives. I: K.S. Kristensen \& J. RahbekClemmensen (red.), Greenland and the International Politics of a Changing Arctic: Postcolonial Paradiplomacy between High and Low Politics. Routledge: 
Routledge Research in Polar Regions, s. 11-27. https://doi.org/10.4324/9781315162645-2

Jacobsen, M. \& Herrmann, V. (2017). Introduction: Arctic International Relations in a Widened Security Perspective. Politik, årg. $20 \quad$ (3), s. 6-14. https://doi.org/10.7146/politik.v20i3.97174

Kleivan, I. (1999). Sprogdebatten. I: J. Lorentzen, E. Jensen and H. Gulløv (red.), Inuit, kultur og samfund - en grundbog i eskimologi. Aarhus: Systime.

Kristensen, K. S. \& Rahbek-Clemmensen, J. (2018). Greenland and the International Politics of a Changing Arctic: Postcolonial Paradiplomacy between High and Low Politics. Routledge: Routledge Research in Polar Regions. https://doi.org/10.4324/9781315162645

Langgård, K. (1998). An examination of Greenlandic awareness of ethnicity and national self-consciousness through texts produced by Greenlanders 1860s-1920s. Études/Inuit/Studies, 1 January 1998, årg. 22(1), s. 83-107.

Lauritzen, P. (1997). Philip Lauritzen i Grønland. 21 års journalistik, (Red: A. Uhd Jepsen), København: Tiderne Skifter.

Lynge, F. (1999). Selvstcendighed for Grønland? København: Arctic Information. Lynge, F. (2002). Den vanskelige tango - en indvendig rundtur i Riget / Tango Nalunartoq.Naalagaaffifiup iluanut pulatt. Nuuk: Atuagkat.

Naalakkersuisut (2019). Kommissorium for Forfatningskommissionen offentliggøres, 29. marts 2019. Tilgængelig på: https://naalakkersuisut.gl/da/Naalakkersuisut/ Nyheder/2019/03/2903_forfatningskommission [Tilgået d. 4. maj 2019].

Petersen, H. (2006). Grønland $i$ Verdenssamfundet. Udvikling og forandring af normer og praksis, Nuuk: Atuagkat.

Petersen, R. (1991). The Role of Research in the Construction of Greenlandic Identity. North Atlantic Studies, årg. 1(2), s. 17-22.

Sejersen, F. (1999). At være grønlænder - hvem sætter grænserne? I: J. Lorentzen, E. Jensen and H. Gulløv, (red.), Inuit, kultur og samfund - en grundbog i eskimologi. Århus: Systime, s. 126-131.

Skydsbjerg, H. (2002). Selvstændighed, men..., Sermitsiaq, nr. 48, s. 22.

Skydsbjerg, H. \& Turnowski W. (2016). Massivt flertal for selvstændighed. Sermitsiaq.ag. Tilgængelig på: http://sermitsiaq.ag/node/192275 [Tilgået d. 22. november 2018].

Statsministeriet (2009). Lov om Grønlands Selvstyre. Tilgængelig på: http://www.stm.dk/multimedia/selvstyreloven.pdf [Tilgået d. 21. november 2018].

Sume - lyden af en revolution (2014). [film] Inuk Silis Høegh \& Emile Hertling Péronard. Anorak Film.

Søbye, G. (2013). Modernization and Heritage. Ilisimatusarfik, Nuuk: Forlaget Atuagkat. Sørensen, A.K. (1983). Danmark-Grønland i det 20. århundrede - en historisk oversigt, København: Nyt Nordisk Forlag 
Thisted, K. (2017). The Greenlandic Reconciliation Commission: Ethnonationalism, Arctic Resources, and Post-Colonial Identity. I: L.-A. Körber, S. MacKenzie \& A.S. Westerstahl (red.), Arctic Environmental Modernities From the Age of Polar Exploration to the Era of the Anthropocene. Basingstoke, UK: Palgrave Macmillan, s. 231-246. DOI: https://doi.org/10.1007/978-3-319-39116-8_14

Thomsen, H. (1998). Ægte grønlændere og nye grønlændere - om forskellige opfattelser af grønlandskhed. Den Jyske Historiker, nr. 81, s. 21-55.

Turnowski, W. (2017). Selvstændighed kun uden forringelser. Sermitsiaq.ag. Tilgængelig på: https://sermitsiaq.ag/node/195511[Tilgået d. 22. november 2018].

\section{Noter}

ii Rebekka J. Knudsen er i dag selvstændig konsulent, men var ved temanummerets begyndelse ansat hos Greenland Perspective.

ii For mere om det dansk-grønlandske forhold se bl.a. Finn Lynges Den vanskelige tango (2002) og Selvstcendighed for Grønland? (1999), Martin Breums Balladen om Grønland (2014) og Ulrik Pram Gads National Identity Politics and Postcolonial Sovereignty Games: Greenland, Denmark, and the European Union.

iii Dokumentarfilmen Sume - lyden af en revolution af Inuk Silis Høegh og Emile Hertling Péronard fortæller om den tætte relation mellem musikken og den grønlandske samfundsudvikling i 1970'erne.

iv Som ikke spillede harmonika, men var digter.

${ }^{v}$ Et godt indtryk af tiden op til og efter Hjemmestyrets indførelse kan fås ved at samlæse: Philip Lauritzen i Grønland. 21 års journalistik, Skydsbjergs artikel 'Selvstændighed, men...', og Sørensens Danmark-Grønland $i$ det 20. århundrede - en historisk oversigt.

${ }^{v i}$ For mere om sikkerhedspolitik i Arktis, se da Tidsskriftet Politiks temanummer 3, 2017: 'Arctic International Relations in A Widened Security Perspective'. Kan downloades frit via dette link: https://tidsskrift.dk/politik/issue/view/6917

vii Som skrevet i Selvstyrelovens $§ 12$ : "Naalakkersuisut kan med fremmede stater og internationale organisationer forhandle og indgå folkeretlige aftaler på rigets vegne, herunder forvaltningsaftaler, som alene vedrører Grønland og fuldt ud angår overtagne sagsområder”. For analyser af, hvordan Grønland forvalter - og i nogle tilfælde forsøger at udvide - denne udenrigspolitiske kompetence, se da: Petersen 2006; Ackrén, 2014; Jacobsen, 2015, 2019ab; Gad, 2016; Kristensen og Rahbek-Clemmensen, 2018; Jacobsen og Gad, 2018.

viii Hvad der definerer grønlandsk identitet og hvem, der kan kalde sig grønlændere bliver også ofte hyppigt debatteret. For mere om denne debat, se bl.a. Petersen 1991; Langgård 1998; Thomsen 1998; Kleivan 1999; Sejersen 1999; Gad 2004; Høiris \& Marquadt 2011; Søbye 2013; Gad 2017; Thisted 2017.

ix Se Bjørst 2012 og 2017 for mere om den grønlandske klimadebat. 